\title{
Sobre Desenho: “Nem consolo, nem remorso" de Inês Araujo
}

\section{Aldo Victorio Filho ${ }^{1}$}

1 Professor Associado do Instituto de Artes da UERJ; Docente do Programa de pós-graduação em Artes - PPGARTES e do Programa de pós-graduação em Educação - PROPED, ambos da UERJ. Graduado em Gravura pela Escola de Belas Artes UFRJ e Licenciado em Educação Artística. UERJ. Professor visitante da Facultad de Belles Arts da Universitat de Barcelona 2017/2018, Procientista e Cientista do Nosso Estado - FAPERJ.

E-mail: avictorio@gmail.com; Orcid: https://orcid.org/0000-0002-7132-8615 
Relutei embora instigado a escrever sobre a exposição "Nem consolo, nem remorso"2 da artista Inês Araujo. O que dizer e de forma adequada e justa, amante confesso dessa técnica específica, sobre um trabalho que me surpreendeu sendo a concisão de todos os fundamentos e dimensões do que tenho como o desenho?

Contudo, o exercício do embate contra os limites da palavra frente à inesgotabilidade da arte me permitiu nessa peleja, com toda a modéstia de quem dispõe apenas da linguagem, avançar mais na interlocução da obra em questão. Afinal, pensar sobre o que desfrutamos reedita, se não a plenitude da experiência, algo do sabor que nos marcou.

Apresentada em uma das salas do Paço Imperial no Rio de Janeiro, a exposição se valeu dos benefícios do espaço de modo a não retrair ou dissipar a potência de cada trabalho que compunha seu conjunto como corpo completo e consistente. Um trabalho realizado, não como junção de obras mais ou menos coesas, mas, numa rede de projeções poéticas que por meio de concordâncias visuais se efetivou com corporeidade completa, articulada e vigorosa.

O espaço solene do antigo prédio, a despeito do contraste temporal de seu desenho com os desenhos que abrigava, participou positivamente do jogo visual das imagens dos diversos cadernos dispostos na vitrine plana e demais suportes fixados nas paredes. Promovendo, obras e espaço, certa flutuação dos traços/gestos tão viscerais que pareciam ainda manter parte do movimento que os produziu, parte do corpo autor. Rastro, indício, ausência eloquente no excesso de presença do que ali não mais estaria, mas, restava.

Eu sou aquele, que tendo-se perdido de vista desejou ver na marca da sua ausência o olhar do outro de onde a sua presença irá surgir (Mondzain, 2015:71)

Um desenho sem traição, portanto, feixe visual de presenças pretéritas e convocação de presenças futuras. Aquelas que chegam diante das obras, olhares estrangeiros, olhares que nada sabem do que encontrarão, do que estaria nas páginas anteriores ou posteriores aquelas expostas dos cadernos plenos. O desenho como cais aberto ao nosso olhar que apenas busca... busca atender ao chamado sem eco das imagens.

\footnotetext{
${ }^{2}$ Exposição de Inês Araújo realizada no Paço Imperial, Rio de Janeiro abril a julho de 2019.
} 
Ocupando mesas-vitrines e paredes, os desenhos foram expostos em cadência e ordenação mais próximas da música, da esfera sonora, do que do campo estritamente visual. Cada imagem evidenciava sua completude com uma sonoridade interminável, para muito além do atrito original dos materiais, papéis, lápis, etc.. Um som deflagrado no tempo da obra que reverbera onde esta está. O som visual do que não consola nem se arrependeria... Reitero, um desenho sem traição que traz, portanto, o corpo denso de sua realização, um corpo ancestral, eloquentemente rigoroso em sua inquisição. Como se a arte desse seu tempo não mais recordasse o tempo quando se elaboravam postulados e ou assertivas, apenas e antes de tudo, o desenho agudo de Inês golpeia o olhar do público com a experiência profunda que só se vive diante da lealdade da arte, experiência da qual decorrem as perguntas insolúveis que habitam o fundo sem fundo humano. Algo sobre o que vem antes do nome, que provoca o gesto fatal que redundará na marca humana no mundo.

Nas palavras de Mondzain (idem, pag.32), diz-nos alguma coisa porque diz coisas sobre nós. Como se o maior estímulo à experiência estética fosse antes o gesto do que o objeto que dele decorre.A aludida sonoridade da mostra, se evidenciava no ritmo e nos intervalos entre cada traço e cada suporte rompido pela articulação entre todas as superfícies desenhadas. $E$ tal sensação emergia dos cadernos que, com certa sedutora provocação, exibiam apenas uma de suas páginas, como exibia o interdito das tantas outras inalcançáveis pelo olhar, mas, indiscutivelmente módulos da sinfonia. Tal jogo, presença e ausência, constituiu outra importante dimensão ao trabalho, sob o desenho há desenhos. Uma metáfora materializada na concretude dos desenhos frente à experiência sem socorro do público.

\section{Referência bibliográfica:}

MONDZAIN, Marie-José. Homo spetactor: ver>fazer ver. Lisboa: Orfeu Negro, 2015. 